\title{
Capacities of Agents of Change in Promoting SATRIYA Codes of Conduct in Yogyakarta Special Region Government
}

\author{
Ambar Teguh Sulistiyani \\ Departement of Public Policy and Management \\ Fakultas Ilmu sosial dan Ilmu Politik UGM \\ Yogyakarta, Indonesia \\ atsulis@yahoo.co.id
}

\author{
Agnes Sunartiningsih \\ Departement of Social Development and Welfare \\ Fakultas Ilmu sosial dan Ilmu Politik UGM \\ Yogyakarta, Indonesia \\ agnes@ugm.ac.id
}

\author{
I Made Krisnajaya \\ Departement of Public Policy and Management \\ Fakultas Ilmu sosial dan Ilmu Politik UGM \\ Yogyakarta, Indonesia \\ imadekrisnajaya2015@gmail.com
}

\author{
Muammar Yuliana \\ Departement of Public Policy and Management \\ Fakultas Ilmu sosial dan Ilmu Politik UGM \\ Yogyakarta, Indonesia \\ moeammary@gmail.com
}

\author{
Kristi Yuliani \\ Departement of Public Policy and Management \\ Fakultas Ilmu sosial dan Ilmu Politik UGM \\ Yogyakarta, Indonesia \\ yuliani.kristi@gmail.com
}

\begin{abstract}
Institutionalization of SATRIYA codes of conduct has been an integral part of Yogyakarta Special Region government's efforts to improve their capacities in delivering public services. SATRIYA is now a subject of massive and intensive socialization and internalization carried out by the Bureau of Organization which covers almost all levels of government units. However, the institutionalization of SATRIYA has not been a satisfaction. Therefore, in 2014 the government formed a group of agents of change which consisted of selected civil servants from all units of government. The forming of the group has been a strategic step promoting SATRIYA codes of conduct in the whole Yogyakarta Special Region government. The Group's job is to put SATRIYA principles into action plans consisting task breakdown structures and a list of activities representing all principles of SATRIYA. All civil servants in Yogyakarta Special Region government are expected to comply with the action plans as a set of what-to-do guidance. The most challenging task of the Group is to facilitate civil servants to orientate their actions to SATRIYA principles. One of the Group's critical success measures is the capacity to develop a conducive-workplace environment for SATRIYA principles to be put into practice accordingly. Therefore, the action plans produced by the Group should provide effective role model, slogans and symbols to promote SATRIYA as a common set of normative standards and value patterns in Yogyakarta Special Region government.
\end{abstract}

Keywords - Capacities; Agents of Change; SATRIYA Codes

\section{INTRODUCTION}

The implementation of government codes of conduct in the environmental governance of Special Region of Yogyakarta (Daerah Istimewa Yogyakarta) became increasingly important after the enactment of laws No 13 of 2012 [1] regarding the privileges of Special Region of Yogyakarta. The spirit of cultural change in bureaucratic institutions was programmed in Medium Term Regional Development Plan (RPJMD) and translated into Terms used in Regional Budget (APBD). The concepts of chivalrous character in the form of unwavering attitude on moral teachings such as sawiji, greget, sengguh, mingkuh and semangat golong gilig (RomoYuwono, 2015) [2], need to becontinously upgraded. Whereas, based on the acronym SATRIYA stands for selaras, akal budi luhur-jati diri, teladan-keteladanan, rela melayani, inovatif, yakin percaya diri, and ahli-profesional (Harmony, NobilityIdentity, Exemplary, willingness toserve, innovative, selfconfident, and professional expert). The purpose of SATRIYA codes of conduct implementation is to improve the conducive working environment to support public services in local government. That policy is appropriate to form the working codes of conduct of Local Government Organization (Note: Organisasi Perangkat Daerah (OPD) that carries on the norms and ethical values efficiently and effectively. Although the socialization program and codes of conduct dissemination of SATRIYA codes of conduct has been organized since 2009 
the result is yet to be satisfying. From 34 Local Government Organizations, there are nine that experience the decreasing of the socialization intensity and SATRIYA codes of conduct internalization. This condition means that the Local Government Organization heed to be assisted in the institutionalization of SATRIYA codes of conduct, in order to achieve the improvement in norms and values of SATRIYA codes of conduct in the joints of Special Region of Yogyakarta governance. SATRIYA is not just a government culture, but also a code of conduct. SATRIYA is a guideline formulation which contains a detailed explanation of the values, indicators of attitudes and behaviors of government apparatus. SATRIYA codes of conduct consist of 31 indicators and 169 behavior guidelines.

Understanding the codes of conduct according to Giorgini at all (2015) [3] codes of conduct and professional guidelines: expressing ignorance regarding guidelines, use of internal compass in absence of clear guidelines, and thinking of guidelines as inflexible, idealistic, and representing a best case scenario.(Popescu, 2001) [4] The code of conduct also functions as an additional set of control indicators on suppliers (Rob and Ans-Kokl, 2001) [5] Codes can create strategic documents in organizations for moderating employee behavior and reducing unethical actions. (Stevens, 2009) [6] The prevalent of codes should continue to increase the government (Schwartz, 2002) [7] Code of ethic is a part of the corporate culture (Herold and Stehr, 2010)[8].

The focus of cultural change in the governance system of Yogyakarta is the implementation of government codes of conduct. Socialization, dissemination and advocacy of SATRIYA codes of conduct by the bureau of the organization have been done sustainably from 2009 until now. In realizing SATRIYA codes of conduct, Yogyakarta Governor regulation No. 53 of 2014 [9], regarding the guidelines for cultural implementation which contains indicator achievements was published. These indicators reflect the excellence of apparatus' character in a system of government that will form local wisdom.

The implantation of cultural values is not easy, because it requires a long and gradual process. The process starts from the cognitive, affective, psychomotor and conatife. Recognizing that the internalization of SATRIYA codes of conduct is difficult, the programmed movement through the establishment of the agent of change in Local Government Organization has been done. The problem faced by the government of Yogyakarta is the agent of change's capacity in promoting SATRIYA codes of conduct to Human Resources in every Local Government Organization.

This research used research action approach. During the research, researcher team also gave advocative training to Bureau Secretary Regional Organizations .The research used Quantitative methods with questionnaires filled out by 340 respondents from the 34 Organization of Local Government. The detaile dexplanation was conducted from qualitative method with interview techniques. Quantitative analysis was performed using descriptive statistics with SPSS method. In addition, the data and information in the form of words were analyzed using qualitative descriptive.

\section{RESEARCH METHODOLOGY}

The method used in this study is a qualitative descriptive study. Quantitative descriptive study was employed for this research in Capacities of Agents of Change in Promoting SATRIYA Codes of Conduct in Yogyakarta Special Region Government.

\section{CAPACITY OF THE AGENT OF CHANGE}

The agent of change undertakes the management of change in the Local Government Organization. To carry out this task, the agent of change needs the proficiency of management especially "Information roles. As stated by Robbins (2000) [10], Information consists of monitor, disseminator, and spokesperson. Through the agent of change, the quality of the SATRIYA codes of conduct apparatus in the organization can be improved. Due to the establishment of positive situation, the organization atmosphere is getting well. Donaldson and Ko (2010) [11] considered the positive organization as a subset of positive institution. That opinion leads to the positive condition of organizational psychology. Based on Seligman and Csikszentmihalyi (2000) [12], Positive psychology is "the science of positive subjective experience, positive individual traits, and positive institution".

Social learning process is required in order to internalize the values and norms. Thereby, the agent of change to drive the apparatus' Ensoulment towards SATRIYA codes of conduct need to perform a cognitive change. As mentioned by Luthans (2011) [13], "social cognitive theory identifies five capabilities used to initiate, regulate, and sustain their behavior: symbolizing, forethought, vicarious/modeling learning, self regulation, and self reflection".

The change of bureaucratic behavior to carry out the functions effectively is required. There are four dominant behaviors in the bureaucracy, which are autocratic, custodial, supportive, and collegial. David (1985) [14] also mentioned that the change of behavior intended to achieve a stimulant and collegial characteristics.

The agent of change always has a positive side in ushering a transition to construct the changes. A model in the process of change should be followed by the agent of change. With this model, it will help encouraging the positive attitude to the environment. As mentioned by Kaifi and Noori (2011) [15], "Organizations that value accountability and transparency are the ones that are more successful during time of organizational change".

To do the effective process of socialization, dissemination, and advocacy, the agent of change needs a strong leadership. Therefore, the capacity of the agent of change becomes a main booster in the process of change. The effort of organizational codes of conduct will be successful if it has strong management and leadership as well as solid and substantial vision. According to Effendi (2005) [16], there are five things to focus, they are the supporting values of the vision; 
motivation that able to mobilize the support for change; precise ideas and strategies; and a clear purposes that communicated to the members as well as the ethical performance that applies proper remuneration.

In fact, everyone needs motivation to make a change. In corresponding with the Effendi's opinion, Chandra sekar (2011) [17 ]said that "the motivation is present in every life function".

The changes on behavior in volue the interaction from other parties. The agent of change tries to keep up with the interaction in order to ensure it goes on effectively and is able to produce an adequate transition. Gibson (2012) [18] said, " A person's behavior in any situation involves the interaction of that individual's personal characteristics and the characteristics of the situation". Keban (1999) [19] also stated that the enhancement of the capacity for cultural socialization increasingly important.

\section{THE INSTITUTIONALIZATION OF GOVERNMENT CODES OF CONDUCT BECOMES THE APPARATUS' CHARACTER.}

The character of apparatus that has a strong compatibility and nobility can be obtained through the continuous implementation of SATRIYA codes of conduct. If those two things are formed, it will be easier for the apparatus to be a role model and capable of being someone else's role model (note: teladan-keteldanan). A positive atmosphere will be formed, so that every person is aware of their role as a partner and someone else's service (note: rela melayani). A mature soul of the apparatus will form an earnest effort to constantly do the innovation and establish the professionalism. If all those things are formed, it will obtain an identity that has a self-confident which is ideal and balanced.

SATRIYA codes of conducture expected to be the officers and employees' soul and character. In order to improve the quality of apparatus, strategic steps are required. The first step is changing the apparatus' mindset about the importance of SATRIYA codes of conduct. Any good concepts without the understanding of the apparatus will not be done well. It means that the concepts is only applicable on paper (document) but never be materialized in reality. Second step is putting the concepts into the policies of Local Government Organization. This step needs to be done in order to implement the official's commitment to each Local Government Organization. The third one, inserting the SATRIYA codes of conduct into the program that covered in the resources utilization so it can be implemented well. The fourth step is describing in detail the program into action plans or activities, so that the codes of conduction be scheduled in real action. Fifth step, allocating resources and adequate time in carrying out the overall steps. Along with these steps, the government codes of conduct can be fully implemented into the real agenda.

The capacity of the agent of change in instituting SATRIYA codes of conduct must be supported by a large capacity. Keban (1999) [19], stated that the development of operational process requires the development of human resources. The agent of change is always given the guidance of conceptual ability, managerial, operational, and technical. Some of the activities to enhance the capacity of agent of change can be seen on the table below.

TABLE I. ENHANCEMENT CAPACITY OF RENEWAL AGENCY 20152016

\begin{tabular}{|l|l|l|l|}
\hline Activities & Frequency & Coordinator & Result \\
\hline $\begin{array}{l}\text { Technical } \\
\text { Guidance }\end{array}$ & $\begin{array}{l}2-3 \times \text { xer } \\
\text { years }\end{array}$ & $\begin{array}{l}\text { Bureau of } \\
\text { Organization }\end{array}$ & $\begin{array}{l}\text { The readiness of the } \\
\text { agent of change }\end{array}$ \\
\hline $\begin{array}{l}\text { Action plan } \\
\text { formulation }\end{array}$ & 2 x per years & $\begin{array}{l}\text { Bureau of } \\
\text { Organization }\end{array}$ & $\begin{array}{l}\text { Action plan } \\
\text { document }\end{array}$ \\
\hline $\begin{array}{l}\text { Monitoring } \\
\text { the Local } \\
\text { Government } \\
\text { Organization }\end{array}$ & Constantly & $\begin{array}{l}\text { Agent of } \\
\text { change }\end{array}$ & $\begin{array}{l}\text { New problems and } \\
\text { challenges }\end{array}$ \\
\hline
\end{tabular}

Source: Bureau of Organization and UGM (University of GadjahMada), 2015 and 2016

The accompaniment is done programmatically, involving all agents of change in Local Government Organization. The researchers provide training material, technical guidance, and action plan references. Employee's responses to the presence of the agent of change are:

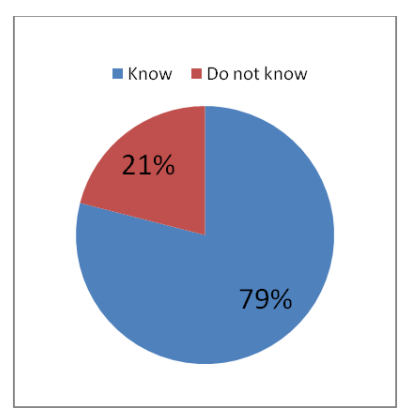

Fig 1. Knowledge of the agents of change.

Source: Monitoring and Evaluation, Bureau of Organization, 2015

There are $79 \%$ of respondents who knew the agent of change's existence and $21 \%$ did not know. This problem needs a special attention. The performance of the agent of change becomes less functional and effective when $21 \%$ of respondents are not aware of the agent of change's existence.

\section{THE AGENT OF CHANGE IN THE IMPLEMENTATION OF SATRIYA CODES OF CONDUCT}

The implementation of SATRIYA codes of conduct as government codes of conduct should be done by all components, particularly the structural officials who become the central in giving the example, encouragement, and determination of strategic policy. Meanwhile, the Bureau of Organization is the main facilitator organizing the entire agent of change throughout Local Government Organization. The agent of change who has received the material is expected to move forward until operational level.

Plan for the implementation of SATRIYA codes of conduct that attached to the Local Government Organization program and activities has been made. The agent of change actively delivers this plan from the leader to the general functional officials. The agent of change consists of civil servants who are selected from all government units. The establishment of this group has been a strategic step promoting SATRIYA ethics throughout the government of Yogyakarta. 
In order to apply SATRIYA codes of conduct, therole of the agent of change are: 1. Providing an understanding to apply of SATRIYA codes of conduct. 2. Encouraging applying SATRIYA codes of conduct. 3. Becoming the Governance and Cultural Change Agents in the implementation of socialization and internalization. 4.Cultivating the awareness in using SATRIYA employees pin.

In the process of institutionalization, the agent of change is attached to the echelons. This is expected to provide an example and give the understanding that goodness can be introduced. In accordance with Havelock's formulation and idea (1973) [20], the agents of change are the people who supports the social changes or innovation plans. Nasution stated that, the introduction and implementation of the ideas that are known as innovative is done so there will be an improvement in people's life[21].

The agent of change is always optimist the changes that desired, as well as the structured and systematic change which can be done. These agents in the corridors, carries out the series of work that are known as the action plan. This chart shows about action plan implementation:

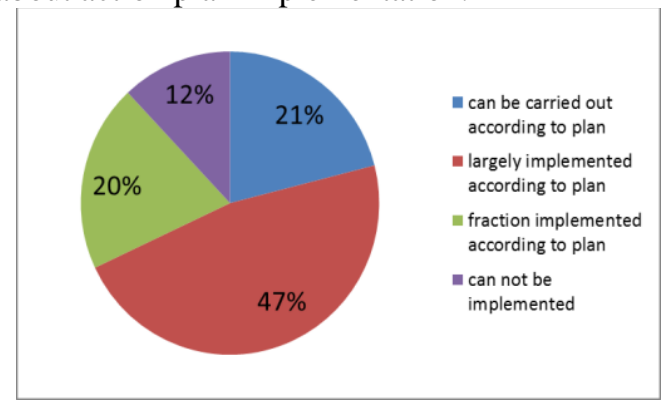

Fig 2. Implementation of action plan

Source: Monitoring and Evaluation, Bureau of Organization, 2015

According to the results taken from Bureau of Organization's monitoring, the implementation agent of change can be carried out according to plan by $21 \%$, largely implemented according to plan by $47 \%$,fraction implemented according to plan by $20 \%$, and cannot be implement tedby $12 \%$. When the agent of change has performed their duties in each Local Government Organization, monitoring need to be done to find out the achievement of socialization and internalization of SATRIYA codes of conduct in Local Government Organization in the officials and employees individually.

Starting from the cultural socialization of SATRIYA codes of conduct to all components of Local Government Organization, then it is monitored regarding the leadership and changes in mindset. The beginning of a change is the change of mindset. After the mindset is changed, it is followed by the emergence process of awareness and operational steps. This monitoring is done as an effort to see the level of implementation that has been achieved by each Local Government Organization.

\section{SATRIYA CODES OF CONDUCT IN GOVERNMENT AS MONITORING AGENDA}

The implementation step of government codes of conduct guided by the action plan in the form of clear plan. In coordination with all agents of change of Local Government Organization has composed an action plan. In the process of implementing the action plan, some Local Government Organization shave used symbol and slogan in order to make it easily recognized and understood by the officials or employees. However, the use of symbol and slogan is yet to be effective in influencing behavior. The knowledge of respondents towards the action plan are:

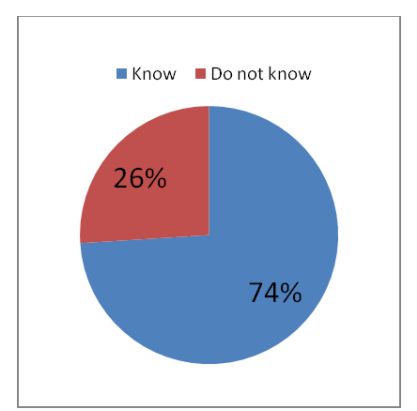

Fig 3. The knowledge towards the action plan

Source: Monitoring and Evaluation, Bureau of Organization, 2015

There are $74 \%$ of respondents knew the action plan and $26 \%$ of them did not know. This condition makes the implementation of action plan less than optimal, because the support is relatively uneven. Under the control of the Bureau of Organization, all Local Government Organizations are monitored programmatically, starting from the changes in mindset, the establishment of real behavior according to the indicator of SATRIYA codes of conduct, to the monitoring and evaluation.

Associated with the serious effort of Bureau of Organization in mobilizing the spirit of socialization through the whole range of Local Government Organization, it is followed by the implementation into the officials and employees' behavior as the indispensable element of the apparatus. Therefore, the realization of SATRIYA codes of conduct requires the efforts of socialization, internalization, leadership, and mindset. Thus, the results of the implementation of SATRIYA codes of conduct in every Local Government Organization need to be tracked.

Through several stages of meeting and dialogue, Government codes of conduct can be implemented in every Local Government Organization by noticing its conditions and variations. Bureau of Organization acts as a coordinator for the implementation of Government codes of conduct. They also launched a program to motivate all Local Government Organization in the Government of Yogyakarta's area. The efforts of motivation are made to accelerate the understanding of the context and the content of Sariya codes of conductbased government codes of conduct. Gradually, Local Government Organization understands the SATRIYA codes of conduct's contents that contains ancestral teachings and translated for the benefit of the rational and ideal of government codes of conduct at the operational level. In order to accelerate and streamline the implementation of 
government codes of conduct, a special team was formed as a stimulus in establishing SATRIYA codes of conduct-based Government codes of conduct. To weld the compactness, the doers of the government codes of conduct will be given the learning periodically and the results will be presented in the monitoring chronologically.

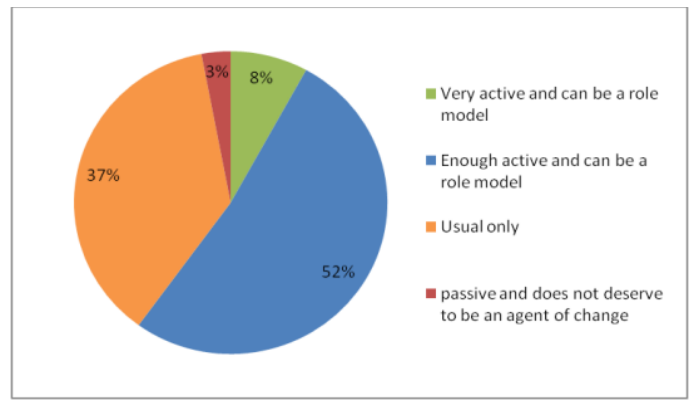

Fig 4. Renewal agency as a role model

Source: Monitoring and Evaluation, Bureau of Organization, 2015

According to the results taken from Bureau of Organization's monitoring, the agent of change shows very active by $8 \%$, active by $52 \%$, mediocre by $37 \%$, and not active by $3 \%$. To improve the implementation of SATRIYA codes of conduct, the activeness of the agent of change needs to be improved by enhancing their abilities and skills. To be a role model, the agent of change should improve the capacity of communication, do the social approaches and enhance the proficiency in actualizing SATRIYA codes of conduct concretely.

\section{CONCLUSION}

The agents of change has been formed by Bureau of Organization to carry out its function in promoting SATRIYA codes of conduct as the government codes of conduct. In order to clarify the work, action plan has been compiled. According to the results of the research, there were $79 \%$ respondents who knew the role and the existence of agent of change. From 34 agents of change, there were $47 \%$ who already had the capacity to promote SATRIYA codes of conduct according to the plan, and only $21 \%$ who had a partial implementation for the plan. This fact certainly shows that the capacity in promoting SATRIYA codes of conduct by the agent of change is still limited. The agent of change faces great challenges to promote SATRIYA codes of conduct. They apply the principles of SATRIYA to be practiced in daily life and in carrying out their duties and functions.

The recommendation to improve the capacity of agents of change are : Program SATRIYA campaign through symbols, slogans, pictures, creating banner, pilot program SATRIYA codes of conduct, the agents of change as a role model, to make an action plan more details.

\section{ACKNOWLEDGMENTS}

This research is intended to assist the government of Yogyakarta Special Region in monitoring the implementation of the activitiesf the agents of change. The results of this research contribute recommendations to increase the capacity of change agents in promoting the SATRIYA codes of conduct.

\section{REFERENCES}

[1] Undang-Undang No 13 Tahun 2012 tentang Keistimewaan Daerah Istimewa Yogyakarta.

[2] Romo Yuwono, 2015 . Coaching of Government Cultural in Government of Yogyakarta Special Region.

[3] Giorgini, Vincent, Jensen T. Mecca, Carter Gibson, Kalsey Medeiros, Michael D. Mumford, Shane Connelly and Lynn D. Devenport, "Researcher Perceptions of Ethical Guidelines and Codes of Conduct", Author Manuscript ; available in PMC 2015 Feb 2, Account Res: 22 (3) : 123-138. (reference)

[4] Popescu, Ada-Iuliana, 2016, “ In Brief: Pros and Cons of Corporate Codes of Conduct", Journal of Public Administration, Finance and Law, Issue 9, Alexandru Ioan Cuza University, Iasi, Romania. (reference)

[5] Rob van Tulder, Ans-Kokl, 2001, "Multinationality and Corporate Ethics: Codes of Conduct and Sporting in the Goods Industry", Journal of International Business Studies 32 (2), pp: 291-301. (reference)

[6] Stevens, Betsy, 2009, "Corporate Ethical Codes as Strategic Documents An Analysis of Success and Failure," EJBO Electronic Journal of Business Ethics and Organization Studies, Vol. 14. No 2 (2009), http://ejbo.jyu.fi/

[7] Schwartz, Mark S. 2002, "The Role of the Business Person in the Fabric of Society," Journal of Business Ethics, Vol. 41. No1/2, pp: 27-43.

[8] Herold, Timo, and Christopher Stehr, 2010, "Developing Hypernorms for Corporate Codes of Ethics,'Journal of Global Strategic Management, Vol. 4. No.1 (June 2010), pp: 100-111. (reference)

[9] Peraturan Gubernur DIY No 53 Tahun 2014 tentang Pedoman Pelaksanaan Budaya Pemerintahan (reference)

[10] Robbins. Stephen P. 2000. 9th . Organizational Behavior. Published by Prentice Hall Upper Saddle River.NJ.

[11] Donaldson. Steward I. and Ia Ko. 2010. "Positive Organizational Psychology, Behavior, and Sholarship : A Review of the Emerging Literature and Evidence Base", The Journal of Positive Psychology, (final version received 1 February 2010, Vol. 5 No:3, May 2010), http://www.tandfonline.com/loi/rpos2, pp: 177-191.

[12] Seligman, Martin E. P., Csikszentmihalyi, Mihaly (2000) Positive psychology: An introduction. American Psychologist, Vol 55(1), Jan 2000, 5-14. http://dx.doi.org/10.1037/0003-066X.55.1.5

[13] Luthans. Fred. 2011.12th. Organizational Behavior: An Evidence-Based Approach. MCGraw Hill Irwin.

[14] Davis. Keith and Joohn W. Newstrom, 1985. Perilaku dalam Organisasi. Penerbit Erlangga.

[15] Kaifi. Belal A. and Selaiman A. Noori. 2011.“Organizational Behavior: A Study of Managers, Employees, and Teams"Journal af Management Policy and Practice (Vol.12(1) 2011

[16] Effendi. Sofian. 2005. "Membangun Budaya Birokrasi untuk Good Governance", Lokakarya Nasional reformasi Birokrasi, (22 September 2005). Kantor Menteri Negara PAN. Yogyakarta.pp:1-5.

[17] Chandrasekar. 2011.'Workp[lace Environment and It Impact on Organizational Performance in Public Sector Organization " International Journal of Enterprise Computing and BusinessSystem (Vol. 1 No: 1 January 2011). http://www.ijecbs.com. (reference)

[18] Gibson. James L. John M. Ivancevich. James H. Donnelly.Jr. Robert Konopaske. 2012. Organization : Behaviror, Structure, Process, MCGraw Hill. Irwin. http://download.portalgaruda.org/article.php?article=250560\&val=6702 \&title=Hubungan $\% 20$ Budaya $\% 20$ Organisasi $\% 20$ Dengan $\% 20$ Perilaku $\%$ 20Birokrasi:\%20Studi\%20Kasus\%20Pada\%20Pemerintah\%20Kabupate n/\%20Kota\%20di\%20Sulawesi\%20Selatan

[19] Keban. Yeremias. (1999). Capacity sebagai Pra kondisi dan Langkah strategis bagi Perwujudan Otonomi Daerah di Indonesia

[20] Havelock, R. G. (1973) The Change Agent's Guide to Innovation in Education. Englewood Cliffs: Educational Technology Publications

[21] Nasution, Zulkarimein. 1990. Prinsip-Prinsip Komunikasi untuk Penyuluhan. Jakarta: Fakultas Ekonomi Universitas Indonesia. 